\title{
Differential Gene Expression of Resistant and Susceptible Sweetpotato Plants after Infection with the Causal Agents of Sweet Potato Virus Disease
}

\author{
Cecilia E. McGregor², Douglas W. Miano' ${ }^{1}$, and Don R. LaBonte \\ School of Plant, Environmental, and Soil Sciences, Louisiana State University Agricultural Center, \\ Baton Rouge, LA 70808 \\ Mary Hoy and Chris A. Clark \\ Department of Plant Pathology and Crop Physiology, Louisiana State University Agricultural Center, \\ Baton Rouge, LA 70808 \\ Guilherme J.M. Rosa \\ Department of Dairy Science, University of Wisconsin, Madison, WI 53706
}

Additional INDEX words. Ipomoea batatas, SPFMV, SPCSV, SPVD

\begin{abstract}
Sweet potato virus disease (SPVD) is one of the most devastating diseases affecting sweetpotato (Ipomoea batatas), an important food crop in developing countries. SPVD develops when sweetpotato plants are dually infected with sweet potato feathery mottle virus (SPFMV) and sweet potato chlorotic stunt virus (SPCSV). To better understand the synergistic interaction between these viruses, global gene expression was previously studied in the susceptible cultivar Beauregard. In the current study, global gene expression between SPVD-affected plants and virus-tested control plants (VT) were compared in 'Beauregard' (Bx) and resistant 'NASPOT 1' (Nas) sweetpotato cultivars at 5, 9, 13, and 17 days post inoculation (DPI). Titer levels of SPFMV and SPCSV were significantly lower in inoculated resistant plants (Nas_SPVD) than in susceptible plants (Bx_SPVD) at most of the time points. Chloroplast genes and cell expansion-related genes (including xyloglucan endotransglucosylase/hydrolases) were suppressed in Bx_SPVD, while stress-related genes were induced. This trend was not observed in resistant NAS_SPVD. Genes related to protein synthesis (e.g., ribosomal proteins and elongation factor genes) were induced in resistant NAS_SPVD at 5 DPI before returning to levels comparable with NAS_VT plants. At this time (5 DPI), individual viruses could not be detected in NAS_SPVD samples, and no symptoms were observed. Induction of protein synthesisrelated genes is common in susceptible plants after virus infection and is generally in proportion to virus accumulation. Our results show that induction of protein synthesis genes also occurs early in the infection process in resistant plants, while virus titers were below the level of detection, suggesting that virus accumulation is not required for induction.
\end{abstract}

Over the past 10 years, sweetpotato (Ipomoea batatas) has consistently been ranked as one of the most important food crops in the world (Food and Agriculture Organization of the United Nations, 2008). The vast majority of production $(\approx 95 \%)$ takes place in developing countries where it is mainly grown by small/subsistence farmers. Stem cuttings provide a convenient way to propagate sweetpotato, but also contribute to the spread of diseases (Clark et al., 1997; Salazar and Fuentes, 2000). Viruses are arguably responsible for the most damaging diseases in sweetpotato (Clark et al., 1997; Fuglie, 2007; Gibson et al., 1997), and mixed infections are common (Colinet et al., 1998). Sweet potato virus disease (SPVD) can lead to yield losses of up to $90 \%$ (Gutierrez et al., 2003), and is caused by dual infection of sweetpotato plants with sweet potato feathery mottle virus (SPFMV) and sweet potato chlorotic stunt virus (SPCSV).

Received for publication 6 Aug. 2009. Accepted for publication 2 Dec. 2009. Approved for publication by the director of the Louisiana Agricultural Experiment Station as manuscript number 2009-306-3946.

This work was funded by the Louisiana Board of Regents Support Fund [LEQSF(2006-08)-RD-B-01] and by the Louisiana Sweet Potato Advertising and Development Commission.

${ }^{1}$ Current address: Biotechnology Centre, Kenya Agricultural Research Institute, P. O. Box 14733, Nairobi, Kenya.

${ }^{2}$ Corresponding author. E-mail: cmcgre1@uga.edu.
SPFMV is a potyvirus (Potyviridae) transmitted by aphids (Aphis gossypii and Myzus persicae) that is widespread in sweetpotato production areas worldwide (Moyer and Salazar, 1989). Most commercial sweetpotato cultivars are described as resistant to SPFMV due to the mild or absent symptom development after infection (Clark and Hoy, 2006; Gutierrez et al., 2003). SPFMV titers are low in these cultivars (Kokkinos and Clark, 2006a), and economic losses due to SPFMV infection by itself are rare (Karyeija et al., 1998).

In contrast, SPCSV infection can lead to significant yield losses in sweetpotato, affecting number of roots and total weight (Gutierrez et al., 2003). This phloem-limited crinivirus (Closteroviridae) is transmitted by whiteflies (Bemisia tabaci and Trialeurodes abutilonea), and typical symptoms include sunken secondary veins, interveinal chlorosis, and sometimes purpling, especially on older leaves (Gutierrez et al., 2003). SPVD develops when SPFMV and SPCSV both infect sweetpotato plants. Dual infection leads to a dramatic increase in SPFMV titers and severe symptoms that include leaf distortion, puckering, chlorosis, fan-leaf, and stunting in susceptible cultivars (Kokkinos and Clark, 2006a). Interestingly, the SPCSV titers do not increase during dual infections, and in some cases, a decrease in SPCSV titers have been observed (Karyeija et al., 2000; Kokkinos and Clark, 2006a). In 1996, 
SPCSV was reported for the first time in the United States in a tissue culture plant (Pio-Ribeiro et al., 1996), and recently, it was detected for the first time in the field (Abad et al., 2007).

Synergistic interactions between viruses are relatively common, especially where potyviruses are concerned. Usually, it is the potyvirus that enhances the infection of another virus (Anjos et al., 1992; Goldberg and Brakke, 1987; Pruss et al., 1997; Vance, 1991; Vance et al., 1995); however, the crinivirus enhances infection of the potyvirus in SPVD infections. The mechanism for the synergistic interaction that leads to SPVD is not understood, but it has been proposed that it involves suppression of gene silencing (Kreuze et al., 2005). Kreuze et al. (2002) identified two unique proteins, p22 and a class 1 RNase III in SPCSV, that were thought to play a role in the synergistic interaction (Kreuze et al., 2002, 2005). However, the same authors recently found that synergism is independent of p22 (Cuellar et al., 2008). It remains to be seen whether RNase III is involved in the process. What is known is that even though RNA silencing-mediated resistance to SPCSV has been obtained in transgenic plants, it did not prevent SPVD development in dually infected plants (Kreuze et al., 2008).

Recently, it has also been reported that the sequence of virus infection affects symptom severity and SPFMV titers in 'Beauregard' sweetpotato plants (McGregor et al., 2009). When plants were infected with SPFMV first, mild symptoms developed. However, when plants were infected with SPCSV first, followed by SPFMV, symptoms were very severe, with an accompanying dramatic increase in SPFMV titers. It seems, therefore, that whatever the synergistic mechanism involved in SPVD development is, once SPFMV resistance has been established, it is difficult to overcome. However, if SPCSV infects first, it seems that the resistance is "blocked" and very severe symptoms develop.

We investigated the differential gene expression among VT 'Beauregard' plants and plants infected with SPFMV alone, SPCSV alone, and both viruses in a previous study (Kokkinos et al., 2006). Various other authors have studied the response of plants to different viruses, mainly in model plants (for reviews, see Whitham et al., 2006; Wise et al., 2007). These studies did not include mixed infections, and as in our original investigation, they concentrated on susceptible plants. General responses observed during potyvirus infection included down-regulation of plastid-associated genes and genes involved in growth and development and up-regulation of defense/stress-related genes and genes involved in protein synthesis (Alfenas-Zerbini et al., 2009; Dardick, 2007; Yang et al., 2007). However, to understand resistance mechanisms, it would be more appropriate to include resistant cultivars. 'NASPOT 1' was originally released in Uganda and is resistant to SPVD (Miano et al., 2008; Mwanga et al., 2003). SPVD symptoms in 'NASPOT 1' are usually limited to mild mottling and chlorotic spots on older leaves and titer levels of SPFMV and SPCSV are lower than in 'Beauregard' (Miano, 2008).

The aim of this study was to compare gene expression over time between resistant ('NASPOT 1') and susceptible ('Beauregard') sweetpotato cultivars after simultaneous infection with the causal agents of SPVD.

\section{Materials and Methods}

Plant material and inoculations. VT sweetpotato cuttings (McGregor et al., 2009) of the cultivars Beauregard and
NASPOT 1 were graft inoculated two weeks after planting (22 May 2007 planting date) with scions affected with SPVD (Bx_SPVD and Nas_SPVD). The scions originated from VT 'Beauregard' plants, previously graft inoculated with the russet crack strain of SPFMV (SPFMV-RC, isolate 95-2) and the U.S. strain of SPCSV (isolate BWFT-3). Control plants were grafted with scions originating from VT plants (Bx_VT and Nas_VT).

Plants were grown in the greenhouse at Louisiana State University (lat. $30^{\circ} \mathrm{N}$, long. $91^{\circ} \mathrm{W}$; temperature lows 21 to $30{ }^{\circ} \mathrm{C}$, highs 32 to $40^{\circ} \mathrm{C}$ ) in $17-\mathrm{cm}$ diameter pots (Elite Azalea; ITLM Horticultural Products, Brantford, ON, Canada) containing autoclaved soil mix consisting of 1 part river silt, 1 part sand, 1 part Redi-earth Plug and Seedling Mix Series (Sun Gro Horticulture, Bellevue, WA), and $3.5 \mathrm{~g}$ per pot of controlledrelease fertilizer (Osmocote 14N-6.1P-11.6K; Scotts-Sierra, Marysville, $\mathrm{OH}$ ). Aphids and whiteflies were controlled by a weekly insecticide spray program alternating among abamectin (Avid 0.15EC; Novartis Crop Protection, Greensboro, NC), a systemic neonicitinoid [acetamiprid (Assail; E.I. DuPont Canada, Mississauga, ON, Canada)], and malathion (Chemisco, St. Louis).

Each cultivar-treatment combination (where treatment refers to virus infection) was replicated six times. The third and fourth fully open leaves from the tip of the main shoot were harvested 5, 9, 13, 17, and $21 \mathrm{~d}$ post inoculation (DPI) from each plant and were immediately frozen in liquid nitrogen and stored at $-80{ }^{\circ} \mathrm{C}$ until RNA extraction. Plants were cut back after 25 DPI and again at 61 DPI, monitored for typical SPVD symptom development, and grafted to an indicator host (Ipomoea setosa) to confirm infection.

Four of the six originally inoculated plants for each cultivartreatment combination were chosen for the experiment based on scion survival after 21 DPI, symptom development until 61 DPI, and symptoms in the indicator host. All further data reported here are based on these selected plants (16 in total, four for each cultivar-treatment combination).

RNA ISOLATION AND QUANTITATIVE REAL-TIME POLYMERASE CHAIN REACTION (Q-RT-PCR) FOR VIRUS TITER DETERMINATION. Leaf material was ground to a fine powder in liquid nitrogen with a mortar and pestle and $\approx 50 \mathrm{mg}$ was used to extract total RNA using the RNeasy Mini Kit (Qiagen, Valencia, CA) following the instructions from the manufacturer. SPFMV and SPCSV titers were determined using TaqMan primer and probe combinations developed by Kokkinos and Clark (2006b) as described by McGregor et al. (2009). SigmaPlot11 (Systat Software, San Jose, CA) was used for analysis of normalized values.

RNA ISOLATION, LABELING, AND ARRAY HYBRIDIZATION FOR MICROARRAYS. Total RNA was extracted for the 16 plants (four each of Bx_VT, Bx_SPVD, Nas_VT, and Nas_SPVD) from samples collected at the four earliest time points $(5,9,13$, and 17 DPI) using the RNeasy Maxi Kit (Qiagen) as previously described (Kokkinos et al., 2006). For each sample, $10 \mu \mathrm{g}$ of total RNA was labeled using the SuperScript Indirect cDNA Labeling System for DNA Microarrays (Invitrogen, Carlsbad, CA) according to the manufacturer's protocol. Samples were labeled with $\mathrm{Cy} 3$ or $\mathrm{Cy} 5$ fluorescent labels (Amersham Biosciences, Piscataway, NJ) and were hybridized onto 32 PICME sweetpotato $13 \mathrm{~K}$ series 1 arrays using the Pronto hybridization kit (Corning, Corning, NY) according to the instruction of the manufacturer. The allocation of samples to slides and dyes was performed such that all experimental groups (i.e., each 
combination of cultivar, treatment, and time point) had four hybridizations (two with each dye: Cy3 and Cy5) with independent biological samples and as much balance as possible (Rosa et al., 2005). The resulting microarray experiment set-up can be seen as a combination of eight loops, with four loops connected over time and four connected over treatment and the order of samples in the loops and the direction of the labeling were different for different loops to ensure that a specific comparison in the loop is not always labeled with the same dye and hybridized together on the same array.

PICME SWeEt POTATo 13K SERIES 1 ARRAY. The Platform for Integrated Clone Management (PICME) Sweetpotato $13 \mathrm{~K}$ Series 1 ARRAY is a cDNA array that contains $\approx 13,000$ sweetpotato expressed sequence tags (ESTs) spotted in duplicate on aminosilane glass slides (GAPS II slides; Corning). The arrays were manufactured by the PICME laboratory at the Austrian Research Centers (Department Biogenetics/Natural Resources, Seibersdorf, Austria). The array was submitted to the Gene Expression Omnibus (GEO) (Barrett et al., 2007; Edgar et al., 2002) by the manufacturer and was designated Platform GPL6498.

Array sCanning, image Quantification, and statistical ANALYSIS. After hybridization, the arrays were scanned with a GenePix Personal 4100A scanner (Molecular Devices, Sunnyvale, CA) and were quantified using GenePix Pro 6 (Molecular Devices). The microarray gene expression data were first normalized to remove potential dye intensity biases using the locally weighted regression and smoothing scatter plot (LOWESS) procedure (Yang et al., 2002). The efficiency of LOWESS normalization was assessed by monitoring $M-A$ plots for data from each array before and after LOWESS normalization. The raw and normalized data were submitted to the GEO and were designated series GSE18869. LOWESSadjusted $\log$ intensities were then analyzed statistically for differential gene expression using a mixed model methodology (Wolfinger et al., 2001) with a $2 \times 2 \times 4$ factorial structure of treatments on a multiple loop design layout (Rosa et al., 2005), including four biological replications per experimental group and 32 slides in total. Gene-specific models included the effects of cultivars ( $\mathrm{Bx}$ and Nas), treatments (VT and SPVD), time points $(5,9,13$, and $17 \mathrm{DPI})$, and their interaction terms, in addition to the dye and slide effects, the latter as random effects (Rosa et al., 2005). F-tests were used to assess the significance of contrasts of interest. The analyses were computed using the MIXED procedure of SAS [SAS Institute, Cary, NC (Littell et al., 2006)]. To account for the multiple testing problem, the probability values were converted to $Q$-values (Storey, 2002) to establish significance based on a false discovery rate (FDR). Expression was considered significant if $Q<0.05$.

GeNe hoMOLOGY, ClASSIFICATION, AND CLUSTERING. Homology (BLASTX E-value < 1E-5) of differentially expressed EST sequences was determined using Blast2GO (Conesa et al., 2005). CAP3 (Huang and Madan, 1999) was used to determine whether ESTs with homology to the same gene were from the

${ }^{\mathrm{z} B e n s o n}$ et al., 2005. same contig. In such cases, only one EST from each contig was used for clustering. Clustering of differentially expressed genes was carried out using Euclidean distances with Cluster 3.0 (de Hoon et al., 2004; Eisen et al., 1998) and results were visualized using TreeView version 1.1.3 (Saldanha, 2004).

Q-RT-PCR FOR MICROARRAY VALIDATION. Five genes were chosen for validation using Q-RT-PCR based on their microarray expression patterns and previous reports of host-gene expression during virus infection. The same RNA samples used for microarray analysis were used for Q-RT-PCR. First-strand cDNA synthesis for the two-step reaction was carried out using qScript cDNA SuperMix (Quanta Biosciences, Gaithersburg, MD) following protocols supplied by the manufacturer. The resulting reaction was diluted $10 \times$, and $2 \mu \mathrm{L}$ of the dilution was used for RT-PCR on the Stratagene MX3005P Real-Time PCR System (Stratagene, La Jolla, CA) using PerfeCta SYBR Green FastMix, Low ROX (Quanta Biosciences), and $400 \mathrm{nM}$ of each primer (Table 1) in a final volume of $15 \mu \mathrm{L}$. Primers were designed using PrimerQuest (Integrated DNA Technologies, Coralville, IA). Standard curves were generated for all primer pairs using a dilution series, and dissociation curves were inspected to detect nonspecific amplification. Actin and 18S ribosomal RNA were tested as housekeeping genes and produced similar results (data not shown). To retain consistency with previous experiments, results presented here were normalized with $18 \mathrm{~S}$ as described in Kokkinos et al. (2006). Q-RTPCR reactions were carried out in duplicate for every sample, and the average was taken for analysis. First-step reactions without reverse-transcriptase were used to verify that no DNA contamination was present. Significance was determined using a three-way analysis of variance (SigmaPlot11) of normalized values.

\section{Results and Discussion}

Symptom DeVelopment AND VIRUS TITERS. The first symptoms appeared 9 DPI on newly emerging leaves of Bx_SPVD plants as mild vein clearing. Symptoms continued to develop, and at 21 DPI, severe vein clearing, puckering, and leaf distortion were observed on young leaves. Symptoms developed uniformly in replicate Bx_SPVD plants at 9 DPI, with only minor observable variations in severity. No symptoms were observed in Nas_SPVD or control (VT) plants of either cultivar in the first 21 DPI.

Table 1. Quantitative real-time PCR (Q-RT-PCR) primers for ribosomal protein L19 (RP L19), ribosomal protein S26 (RP S26), xyloglucan endotranshydrolase 9 (XTH 9), a NAC transcription factor (NAC), and mannose-binding lectin (MBL) used to validate microarray results.

\begin{tabular}{lcll}
\hline Homology & $\begin{array}{c}\text { GenBank } \\
\text { accession no. }\end{array}$ & & \multicolumn{1}{c}{ Primer $\left(5^{\prime}-3^{\prime}\right)$} \\
\hline XTH 9 & EE884374 & FWD & CCA GCC TTA CAC CAT CCA CA \\
& & REV & CTG CCT CCT TTC CCT TGA GA \\
NAC & CB330170 & FWD & GAA ATG CGC CTC CCA ATC TA \\
& & REV & AGG TCG ATC TCG GCA ATG AT \\
MBL & EE875179 & FWD & TCG TCG TTA ACA CTG ACA CGG TGA \\
& REV & TAA AGT ATC CAG CGC GAC CAA CGA \\
RP L19 & CB330692 & FWD & TCT CCA TGG CCA ACT CTC GAC AAA \\
& & REV & ACC ATA TCC AGA ATG ACG GCC CTT \\
RP S26 & CB330307 & FWD & ACT TTC AAG CGA AGG AAT GGT GGC \\
& & REV & TTG GAC AGC ATT TAC CGC AGT TGG \\
\hline
\end{tabular}


Individual virus titers were significantly lower in Nas_SPVD than Bx_SPVD for both viruses at all times, except at 5 DPI and for SPFMV only, at 13 DPI (Fig. 1, A and B). At 5 DPI, SPFMV could be detected by Q-RT-PCR in only a single Bx_SPVD plant. SPCSV could not be detected in any plants at this stage. From 9 to 21 DPI, SPFMV titers in Bx_SPVD plants showed a general increase. SPFMV in Nas_SPVD plants were close to the limit of detection and could not be detected at every time point for all plants. However, SPFMV was detected at least once in each Nas_SPVD plant during the 21 DPI period.

SPCSV showed a dramatic increase in Bx_SPVD plants to 13 DPI and then plateaued. At 9 DPI, SPCSV could be detected in only one Nas_SPVD plant, but after that (13, 17, and 21 DPI), the virus was detected in all Nas_SPVD plants, but at a significantly lower level than in Bx_SPVD plants. No virus could be detected in any of the control plants (VT).

Plants were allowed to continue to grow after 21 DPI and were monitored for typical SPVD symptom development. Mild chlorotic spots and mottling were observed on older leaves of all Nas_SPVD plants after 23 DPI (data not shown). Symptom development in an indicator host (I. setosa) confirmed the expected presence/absence of the viruses in the 16 plants (data not shown).
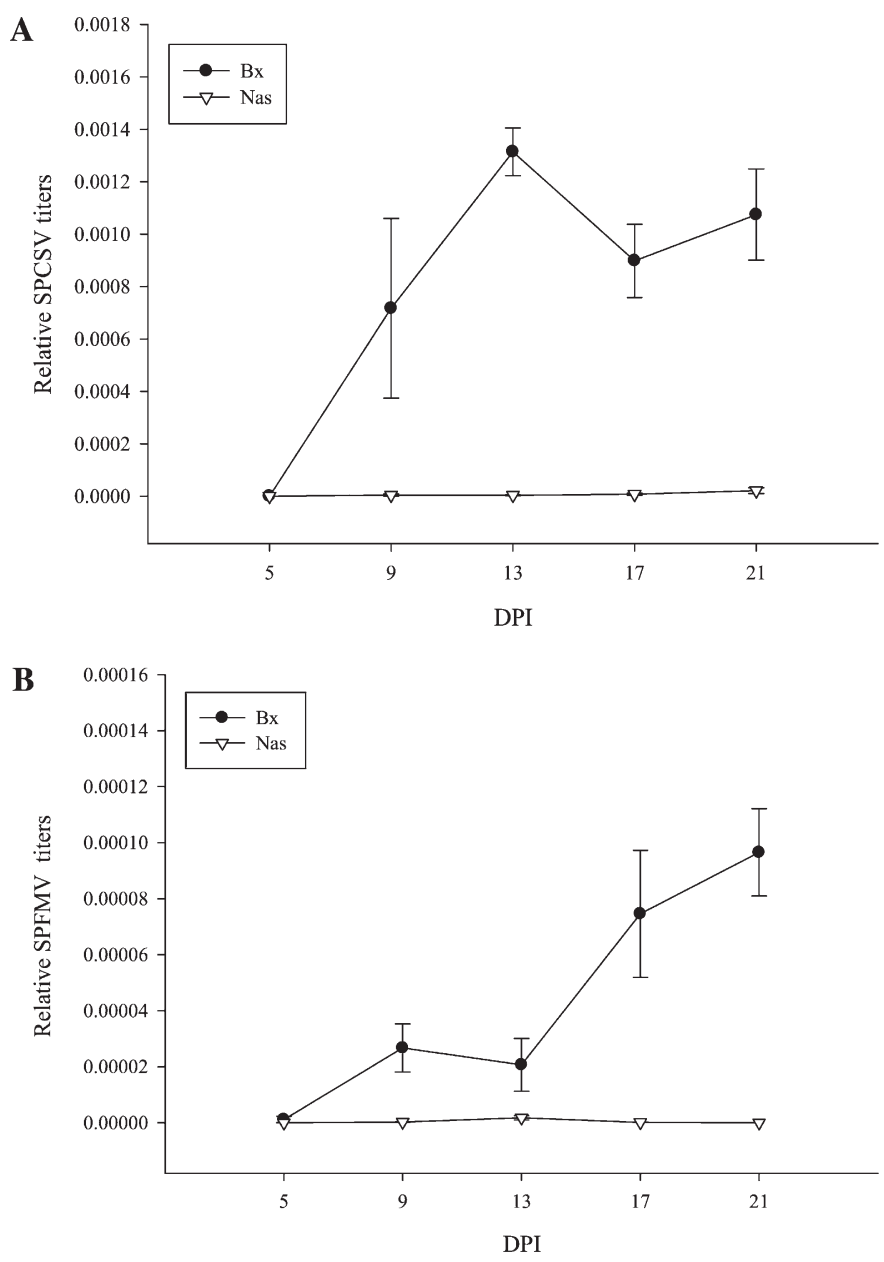

Fig. 1. Relative virus titers for (A) sweet potato chlorotic stunt virus (SPCSV) and (B) sweet potato feathery mottle virus (SPFMV) in 'Beauregard' (Bx) and 'NASPOT 1' (Nas) sweetpotato plants affected with sweet potato virus disease (SPVD) at 5, 9, 13, 17, and $21 \mathrm{~d}$ post inoculation (DPI). Bars indicate SE.
DifFERENTIAL EXPRESSION BETWEEN TREATMENTS IN SUSCEPTIBLE 'BEAUREGARD'. The 157 genes that are differentially expressed between Bx_VT and Bx_SPVD can be clustered according to their expression patterns into four groups using K-means clustering (Fig. 2). The first group (i) represents genes that are suppressed in Bx_SPVD, especially at 17 DPI, and include sporamin and cell wall expansion proteins. Sporamin is the main storage protein in sweetpotato storage roots and it makes up between $60 \%$ and $80 \%$ of total soluble protein in the root (Maeshima et al., 1985). It is encoded by a multigene family that can be divided into two classes (A and B) (Hattori and Nakamura, 1988; Hattori et al., 1989). The suppression of sporamin in SPVD-affected 'Beauregard' has been reported previously (Kokkinos et al., 2006), and suppression of metabolismrelated genes has been described after infection of Arabidopsis thaliana with turnip mosaic virus (TuMV) (Yang et al., 2007). Xyloglucan endotransglucosylase/hydrolases (XTH) and expansins are involved in cell expansion, and suppression of these genes is probably responsible for the stunted growth that is often observed in virus-infected plants. Suppression of cell wall-related genes during virus infection has been observed in Oryza sativa and $A$. thaliana during infection with rice dwarf

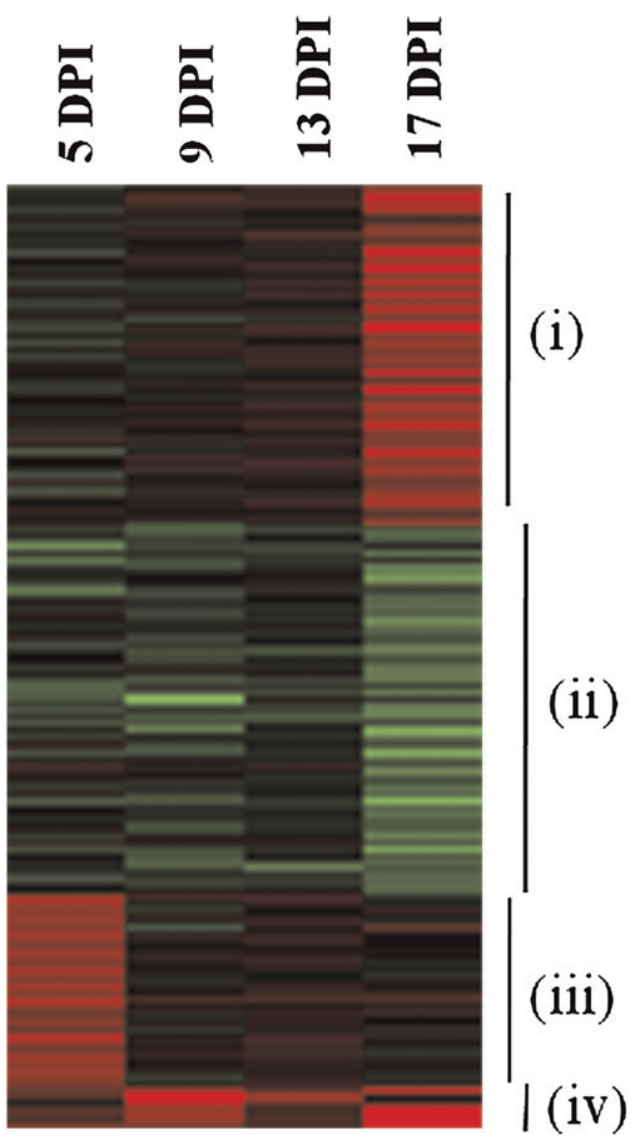

Fig. 2. K-means clustering of $\log _{2}$ ratios of genes differentially expressed $(Q<$ 0.05 ) at one or more time points between virus-tested 'Beauregard' sweetpotato plants and 'Beauregard' plants affected with sweet potato virus disease (SPVD) at 5, 9, 13, and $17 \mathrm{~d}$ post inoculation (DPI). Clustering was carried out with Cluster, version 3.0 (de Hoon et al., 2004; Eisen et al., 1998) and visualized using TreeView, version 1.1.3 (Saldanha, 2004). Red and green indicate genes suppressed and induced in SPVD-affected plants, respectively. The more intense the color, the larger the fold-change between treatments. (To view this figure in color, see the online version of the article.) 
virus (Shimizu et al., 2007) and TuMV (Yang et al., 2007), respectively.

Genes that are induced in Bx_SPVD (Fig. 2, cluster ii) include stress-related genes such as glutathione $S$-transferase, chitinases, and superoxide dismutase, as well as transcription factors. Several other studies have described the up-regulation of stress-related genes in plants infected with viruses (AlfenasZerbini et al., 2009; Dardick, 2007; Kokkinos et al., 2006; Whitham et al., 2006; Yang et al., 2007).

Chloroplast-related genes were suppressed in Bx_SPVD plants, especially at 5 DPI (Fig. 2, cluster iii). We described the same phenomenon in our original study (Kokkinos et al., 2006), and several other publications describe the same effect for other plant-virus interactions (Dardick, 2007; Whitham et al., 2006; Yang et al., 2007). The chlorosis that is often associated with virus infection is related to the down-regulation of plastid genes, but it should be noted that at 5 DPI, we did not observe chlorosis or any other symptoms. However, it is probable that down-regulation of genes would take place before chlorosis is observed with the naked eye.

Histone H1C is the only gene in the fourth cluster (Fig. 2, cluster iv) with known homology. The genes in this cluster are generally suppressed in Bx_SPVD during the majority of the study period. Havelda et al. (2008) found that symptom severity was related to the extent of suppression of specific hostencoded genes (e.g., histone genes). Of the 157 genes differentially expressed between Bx_VT and Bx-SPVD, 61 could not be assigned functions (hypothetical proteins, unknown protein, or no homology).

The results from the comparison of Bx_VT and Bx_SPVD are very similar to our previous study, even though the original study compared only one time point at a much later time (63 DPI). The results also show good agreement with other studies involving various viruses and susceptible host plants (Whitham et al., 2006; Wise et al., 2007).

DIFFERENTIAL EXPRESSION BETWEEN TREATMENTS IN RESISTANT 'NASPOT 1'. The vast majority (137) of the 145 genes differentially expressed between Nas_VT and Nas_SPVD showed significant induction in Nas_SPVD at 5 DPI (Fig. 3, cluster i). Genes involved in protein synthesis (e.g., ribosomal proteins and elongation factor genes) represent $\approx 69 \%(94 / 137)$ of the induced genes. Other genes in the cluster include transcription factors (WRKY, homeodomain proteins, and NAC-like proteins), genes involved in glycolysis (e.g., enolase, fructosebisphosphate aldolase, and glyceraldehyde-3-phosphate dehydrogenase), histone genes, and 21 genes (14\%) with no known function. Interestingly, several of these induced genes (e.g., glyceraldehyde-3-phosphate dehydrogenase and histone genes) are often down-regulated in susceptible plants (Havelda et al., 2008; Senthil et al., 2005). The down-regulation of these specific host-encoded genes in susceptible plants is thought to cause developmental defects associated with symptom development.

Eight genes are suppressed in NAS_SPVD at 5 DPI (Fig. 3, cluster ii). These genes include chloroplast-related genes (Rubisco, ferritin-3, and photosystem ii light-inducible protein), metallothionein, and an ubiquitin-conjugating enzyme. Like other host genes mentioned previously, Rubisco is often down-regulated during infection of susceptible plants (Havelda et al., 2008). The mechanism underlying the patterns of differentially expressed genes in susceptible plants are not understood, but they are specific to particular host-virus in-

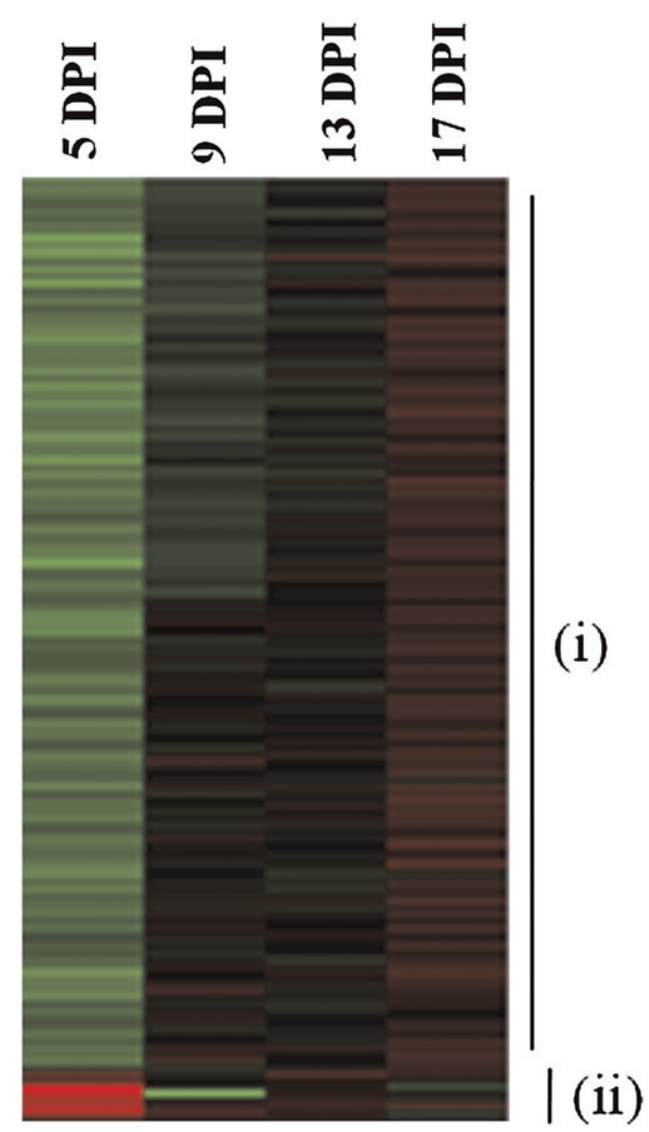

Fig. 3. K-means clustering of $\log _{2}$ ratios of genes differentially expressed $(Q<$ 0.05 ) at one or more time points between virus-tested 'NASPOT 1 ' sweetpotato plants and 'NASPOT 1' plants affected with sweet potato virus disease (SPVD) at 5, 9, 13, and $17 \mathrm{~d}$ post inoculation (DPI). Clustering was carried out using Cluster version, 3.0 (de Hoon et al., 2004; Eisen et al., 1998) and visualized using TreeView, version 1.1.3 (Saldanha, 2004). Red and green indicate genes suppressed and induced in SPVD-affected plants, respectively. The more intense the color, the larger the fold-change between treatments. (To view this figure in color, see the online version of the article.)

teractions (Havelda et al., 2008; Senthil et al., 2005) and this is probably also true for resistant plants.

The induction of ribosomal protein (RP) genes during potyvirus infection of susceptible hosts has been described for plum pox virus (PPV) and TuMV (Dardick, 2007; Yang et al., 2007). We did not observe induction of ribosomal protein genes to the same extent in Bx-SPVD (compared with Bx_VT) in the present study, but did observe it at 63 DPI in the previous study (Kokkinos et al., 2006). In Nas_SPVD, the induction is mainly limited to 5 DPI. After 5 DPI, most of the genes are not statistically $(Q<0.05)$ different between treatments. Induction of genes involved in protein synthesis is thought to be related to the virus's lack of translational machinery, which forces it to use the translational machinery of the host plant. It is not known whether the induction of these genes is due to a signal sent from the virus or whether it is the host that is responding to the hijacking of its translational machinery by the virus. Yang et al. (2007) observed that the highest induction of these genes was observed where virus accumulation was the highest. However, in the present study, no virus could be detected at 5 DPI. Therefore, it appears that the induction of ribosomal proteins in 'NASPOT 1' is unrelated to virus accumulation and it seems 
unlikely that accumulation is due to the hosts' response to hijacking of its translational machinery. It seems more likely that the induction is triggered by a signal from the virus as "prerequisite" to virus accumulation, which then does not take place due to some resistance mechanism. Whether this resistance mechanism is related to the greater induction of these genes in resistant than susceptible plants is unknown at this stage.

DIFFERENTIAL EXPRESSION BETWEEN CUltivars AND TREatments. Comparing differentially expressed genes between the susceptible host ('Beauregard') and resistant host ('NASPOT 1') is complicated by the fact that these two cultivars have very different growth habits. It would therefore be expected that many genes would be differentially expressed due to inherent differences between the cultivars, independent of the treatment (VT and SPVD). Therefore, to compare the results between 'NASPOT 1' and 'Beauregard' we compared genes that are differentially expressed for the cultivar $\times$ treatment and/or cultivar $\times$ treatment $\times$ time interaction (Fig. 4). Using these criteria, 70 genes were differentially expressed for these interaction terms (the lists of genes with fold changes/relative expression shown in Figs. 2-4 are available from the authors).

Many of these genes are differentially expressed late in the experiment (17 DPI). As previously described, SPVD infection suppresses sporamin genes in 'Beauregard', but it does not seem to have the same effect in 'NASPOT 1', where the expression levels for Nas_VT and Nas_SPVD are similar or lower than for Bx_SPVD (Fig. 4). It would be interesting to determine whether 'NASPOT 1' storage roots have inherently lower sporamin content than 'Beauregard' storage roots, or whether the differential expression at this early stage (from a production point of view) is related to the fact that 'Beauregard' storage roots develop much earlier than those of 'NASPOT 1'. XTH9 expression is higher in Bx_VT than in Bx_SPVD, Nas_VT, and Nas_SPVD at 17 DPI (Figs. 4 and 5A). As mentioned previously, lower XTH9 is thought to be related to stunting in virus affected plants (Shimizu et al., 2007; Yang et al., 2007). Because 'NASPOT 1' is a much more compact plant than 'Beauregard', it is not surprising that XTH9 is lower in all treatments of 'NASPOT 1' than Bx_VT. Stunting was not
EE883564, lipid transfer protein

EE880547, no homology

EE881511, hypothetical protein

CB330475, mitochondrial-processing peptidase

EE883844, no homology

EE330071, no homology

EE883070, hypothetical protein

CB330958, chlorophill a/b binding protein

CB330287, cytosolic nucleoside diphosphate kinase

CB330289, ribosomal protein L13a

CB330400', ribosomal

CB330045, chaperon protein 10

CB330896, ribosmal protein L10

CB330692, ribosomal protein 219

CB330951, ribomal protein L19

CB330170, NAC transcription factor

CB330567, ribosomal protein L13

CB330307, ribosomal protein L13

CB330307, ribosomal protein 526

EE879979, sporamin B

EE881385, no homology

EE875179， mannose-binding lectin

EE883845, proteinase inhibitor splti-a

$\mathrm{EE} 880958$, mannose-binding lectin

EE874821, proteinase inhibitor

EE883693, no homology

EE876654, no homology

EE876436, hypothetical protein

EE874822, hypothetical protein

EE876403, WD-repeat protein

EE884089, cytochrome p450 monooxygenas

EE877537, predicted protein

EE878936, WRKY transcription factor

EE883316, glucose-6-phosphate phosphate translocator

EE877553, no homology

EE881626, hypothetical protein

EE874906, hypothetical protein

EE881406, unkown protein

EE883513, annexin p34

EE884021, NADH-ubiquinone oxidoreductase

EE879549, hypothetical protein

EE879502, TBP-associated factor

EE879693, no homology

EE879474, pyruvate kinase

EE878817, sporamin

EE884676, sporamin

EE879524, tronseription factor BTF3

CB33054, transcription factor

CB330564, hypothetical pr

EE875480, no homology

EE877334, no homology

EE877345, no homology

EE877517, no homology

EE879749, RING prot

EE879430， phosphate-induced protein

EE877314, eukaryotic translation initiation facto

EE876369, phosphate-induced protein

EE875806, XTH9

EE878881, sporamin

EE879745, ribosomal protein L18

EE879356, sporamin

EE884375, sporamin

EE884374, XTH9

CB330735, ribosomal protein L24

EE880718, hypothetical protein

CB330720, photosystem II protein I

CB330688, DNA repair protein

EE880403， cytochrome cl

Fig. 4. Hierarchical clustering (centroid linkage) of $\log _{2}$ estimates of genes differentially expressed $(Q<0.05)$ for the cultivar $\times$ treatment and/or cultivar $\times$ treatment $\times$ time interactions. Gene expression was monitored in sweetpotato plants of the cultivars Beauregard (Bx) and NASPOT 1 (Nas) at 5, 9, 13, and 17 d post inoculation (DPI) with virus-tested (VT) control or sweet potato virus disease (SPVD). Clustering was carried out using Cluster, version 3.0 (de Hoon et al., 2004; Eisen et al., 1998) and visualized using TreeView, version 1.1.3 (Saldanha, 2004). The lighter the color, the higher the observed expression. (To view this figure in color, see the (Saldanha, 2004). The lighter
online version of the article.)

observed in Nas_SPVD plants. Genes with differential expression between Bx_VT and Bx_SPVD late in the experimental period (17 DPI) (e.g., NAC transcription factor, Figs. 4 and 5B) are probably related to symptom development in Bx_SPVD plants.

Several genes are up-regulated in all treatments at 17 DPI (Fig. 4). These include mannose-binding lectin (MBL), which is expressed higher in Nas_SPVD than all other treatments at 17 DPI (Figs. 4 and 5C). This gene shows high homology to mannose-specific, jacalin-related lectins that are thought to play a role in specific stress responses (Van Damme, 2008; Van Damme et al., 1996). Induction of ribosomal protein genes in 

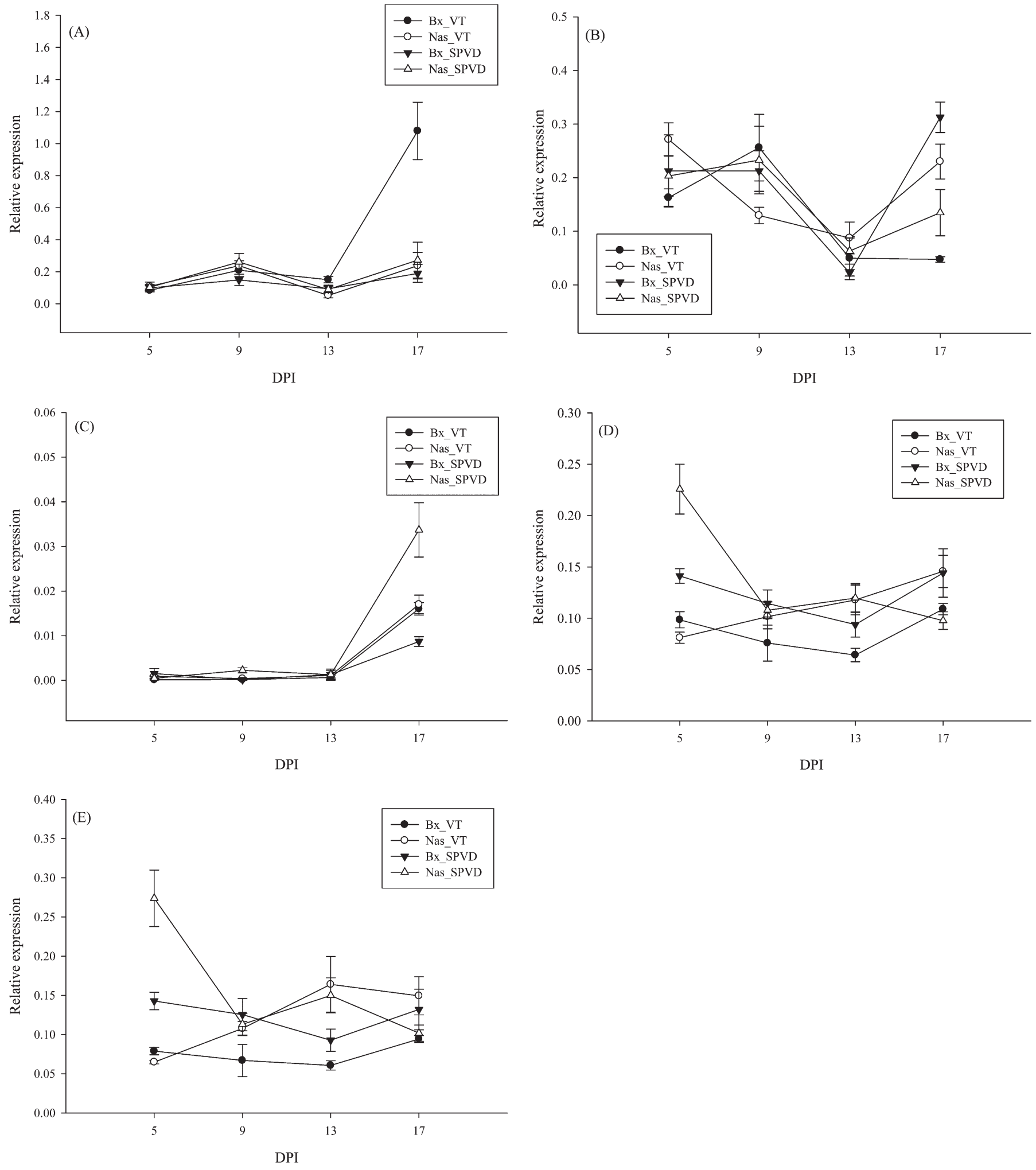

Fig. 5. Quantitative real-time PCR results for (A) xyloglucan endotranshydrolase 9, (B) NAC transcription factor, (C) mannose-binding lectin, (D) ribosomal protein L19, and (E) ribosomal protein S26. Relative expression levels were measured for the four cultivar-treatment combinations 'Beauregard' (Bx) and 'NASPOT 1' (Nas) sweetpotato plants affected with sweet potato virus disease (SPVD) (Bx_SPVD and Nas_SPVD) and virus-tested (VT) control plants (Bx_VT and Nas_VT) at 5, 9, 13, and $17 \mathrm{~d}$ post inoculation (DPI). Bars indicate sE.

Nas_SPVD at 5 DPI is the most striking result of this study (Figs. 4 and 5, D and E). As mentioned before, the induction of ribosomal proteins during virus infection in susceptible hosts has been reported previously (Dardick, 2007; Kokkinos et al., 2006; Yang et al., 2007). However, induction was associated with virus accumulation, which is not the case in 'NASPOT 1'. 
Q-RT-PCR results indicate that the two RP genes tested (RP L19 and RP S26) were also induced in Bx_SPVD (compared with Bx_VT) at $5 \mathrm{DPI}$, but not to the same extent as in 'NASPOT 1' (Figs 5, D and E). Neither virus was detected in Nas_SPVD at 5 DPI, nor were symptoms observed. The induction of RP genes in 'NASPOT 1' at such an early stage is surprising and it is unclear how it relates to resistance.

It would be interesting to see whether the same effect is observed when 'NASPOT 1' is infected with SPFMV alone. 'NASPOT 1' and 'Beauregard' are resistant to SPFMV alone, and it is thought that in 'Beauregard', the resistance mechanism is overcome due to some mechanism related to SPCSV infection. Kreuze et al. (2008) found that even after resistance to SPCSV was engineered using RNA silencing, SPVD still developed after dual infections. It was suggested that immunity to SPCSV might be required to prevent SPVD development. Immunity is generally associated with the absence of virion accumulation and the inability to detect the virus (Parrella et al., 2004). 'NASPOT 1' is not immune to SPCSV, but SPCSV multiplication is reduced compared with 'Beauregard' and the virus was detected later than in 'Beauregard'.

Future research should investigate the response of 'NASPOT 1' to SPFMV and SPCSV alone and whether early upregulation of protein synthesis-related genes is observed during virus infection in other resistant hosts.

\section{Literature Cited}

Abad, J.A., E.J. Parks, S.L. New, S. Fuentes, W. Jester, and J.W. Moyer. 2007. First report of sweet potato chlorotic stunt virus, a component of sweetpotato virus disease, in North Carolina. Plant Dis. 91:327.

Alfenas-Zerbini, P., I.G. Maia, R.D. Fãvaro, J.C.M. Cascardo, S.H. Brommonschenkel, and F.M. Zerbini. 2009. Genome-wide analysis of differentially expressed genes during the early stages of tomato infection by a potyvirus. Mol. Plant Microbe Interact. 22:352-361.

Anjos, R.J., U. Jarfors, and S.A. Ghabrial. 1992. Soybean mosaic potyvirus enhances the titre of two comoviruses in dually infected soybean plants. Phytopathology 82:1022-1027.

Barrett, T., D.B. Troup, S.E. Wilhite, P. Ledoux, D. Rudnev, C. Evangelista, I.F. Kim, A. Soboleva, M. Tomashevsky, and R. Edgar. 2007. NCBI GEO: Mining tens of millions of expression profiles: Database and tools update. Nucleic Acids Res. 35:D760-D765.

Benson, D.A., I. Karsch-Mizrachi, D.J. Lipman, J. Ostell, and D.L. Wheeler. 2005. GenBank. Nucleic Acids Res. 33:D34-D38.

Clark, C.A. and M.W. Hoy. 2006. Effects of common viruses on yield and quality of Beauregard sweetpotato in Louisiana. Plant Dis. 90:83-88.

Clark, C.A., M.W. Hoy, and R.A. Valverde. 1997. The evolving disease situation for sweet potatoes. Louisiana Agr. 40:15-19.

Colinet, D., M. Nguyen, J. Kummert, P. Lepoivre, and F.Z. Xia. 1998. Differentiation among potyviruses infecting sweet potato based on genus- and virus-specific reverse transcription polymerase chain reaction. Plant Dis. 82:223-229.

Conesa, A., S. Gotz, J.M. Garcia-Gomez, J. Terol, M. Talon, and M. Robles. 2005. Blast2GO: A universal tool for annotation, visualization and analysis in functional genomics research. Bioinformatics 21:3674-3676.

Cuellar, W.J., F. Tairo, J.F. Kreuze, and J.P.T. Valkonen. 2008. Analysis of gene content in sweet potato chlorotic stunt virus RNA1 reveals the presence of the $\mathrm{p} 22$ RNA silencing suppressor in only a few isolates: Implications for viral evolution and synergism. J. Gen. Virol. 89:573-582.

Dardick, C. 2007. Comparative expression profiling of Nicotiana benthamiana leaves systemically infected with three fruit tree viruses. Mol. Plant Microbe Interact. 20:1004-1017. de Hoon, M.J.L., S. Imoto, J. Nolan, and S. Miyano. 2004. Open source clustering software. Bioinformatics 20:1453-1454.

Edgar, R., M. Domrachev, and A.E. Lash. 2002. Gene Expression Omnibus: NCBI gene expression and hybridization array data repository. Nucleic Acids Res. 30:207-210.

Eisen, M.B., P.T. Spellman, P.O. Brown, and D. Botstein. 1998. Cluster analysis and display of genome-wide expression patterns. Proc. Natl. Acad. Sci. USA 95:14863-14868.

Food and Agriculture Organization of the United Nations. 2008. Crop production. 8 Dec. 2008. <http://faostat.fao.org/site/567/default. aspx\#ancor>.

Fuglie, K.O. 2007. Priorities for sweetpotato research in developing countries: Results of a survey. HortScience 42:1200-1206.

Gibson, R.W., R.O.M. Mwanga, S. Kasule, I. Mpembe, and E.E. Carey. 1997. Apparent absence of viruses in most symptomless fieldgrown sweet potato in Uganda. Ann. Appl. Biol. 130:481-490.

Goldberg, K.B. and M.K. Brakke. 1987. Concentration of maize chlorotic mosaic virus increases in mixed infections with maize dwarf mosaic virus strain B. Phytopathology 77:162-167.

Gutierrez, D.L., S. Fuentes, and L. Salazar. 2003. Sweet potato virus disease (SPVD): Distribution, incidence, and effect on sweet potato yield in Peru. Plant Dis. 87:297-302.

Hattori, T. and K. Nakamura. 1988. Genes coding for the major tuberous root protein of sweet potato: Identification of putative regulatory sequence in the $5^{\prime}$ upstream region. Plant Mol. Biol. 11:417-426.

Hattori, T., N. Yoshida, and K. Nakamura. 1989. Structural relationship among the members of a multigene family coding for the sweet potato tuberous root storage protein. Plant Mol. Biol. 13:563572.

Havelda, Z., É. Várallyay, A. Válóczi, and J. Burgyán. 2008. Plant virus infection-induced persistent host gene down-regulation in systemically infected leaves. Plant J. 55:278-288.

Huang, X. and A. Madan. 1999. CAP3: A DNA sequence assembly program. Genome Res. 9:868-877.

Karyeija, R.F., J.F. Kreuze, R.W. Gibson, and J.P.T. Valkonen. 2000. Synergistic interactions of a potyvirus and a phloem-limited crinivirus in sweetpotato plants. Virology 269:26-36.

Karyeija, R.F., R.W. Gibson, and J.P.T. Valkonen. 1998. The significance of sweet potato feathery mottle virus in subsistence sweet potato production in Africa. Plant Dis. 82:4-15.

Kokkinos, C.D. and C.A. Clark. 2006a. Interactions among sweet potato chlorotic stunt virus and different potyviruses and potyvirus strains infecting sweetpotato in the United States. Plant Dis. 90:1347-1352.

Kokkinos, C.D. and C.A. Clark. 2006b. Real-time PCR assays for detection and quantification of sweetpotato viruses. Plant Dis. 90:783-788.

Kokkinos, C.D., C.E. McGregor, C.A. Clark, and D.R. LaBonte. 2006. The effect of sweet potato virus disease and its viral components on gene expression levels in sweetpotato. J. Amer. Soc. Hort. Sci. 131:657-666.

Kreuze, J.F., E.I. Savenkov, and J.P.T. Valkonen. 2002. Complete genome sequence and analyses of the subgenomic RNAs of sweet potato chlorotic stunt virus reveal several new features for the genus Crinivirus. J. Virol. 76:9260-9270.

Kreuze, J.F., E.I. Savenkov, W. Cuellar, X. Li, and J.P.T. Valkonen. 2005. Viral class 1 RNase III involved in suppression of RNA silencing. J. Virol. 79:7227-7238.

Kreuze, J.F., I.F. Klein, M.U. Lazaro, W.J. Cuellar Chuquiyuri, G.L. Morgan, P.G. Cipriani Mejía, M. Ghislain, and J.P.T. Valkonen. 2008. RNA silencing-mediated resistance to a Crinivirus (Closteroviridae) in cultivated sweetpotato (Ipomoea batatas L.) and development of sweetpotato virus disease following co-infection with a potyvirus. Mol. Plant Pathol. 9:589-598.

Littell, R.C., G.A. Milliken, W.W. Stroup, R.D. Wolfinger, and O. Schabenberger. 2006. SAS for mixed models. SAS Institute, Cary, NC. 
Maeshima, M., T. Sasakit, and T. Asahi. 1985. Characterization of major proteins in sweet potato tuberous roots. Phytochem. Rev. 24:1899-1902.

McGregor, C., M. Miano, D. La Bonte, M. Hoy, and C. Clark. 2009. The effect of the sequence of infection of the causal agents of sweet potato virus disease on symptom severity and individual virus titres in sweet potato cv. Beauregard. J. Phytopathol. 157: 514-517.

Miano, D.W. 2008. Replication of viruses responsible for sweet potato virus disease in resistant and susceptible sweetpotato genotypes and identification of molecular markers linked to resistance. PhD diss. Louisiana State University, Baton Rouge.

Miano, D.W., D.R. LaBonte, and C.A. Clark. 2008. Identification of molecular markers associated with sweet potato resistance to sweet potato virus disease in Kenya. Euphytica 160:15-24.

Moyer, J.W. and L.F. Salazar. 1989. Viruses and virus-like diseases of sweetpotato. Plant Dis. 73:451-455.

Mwanga, R.O.M., O. B., G. Turyamureeba, and A. Alajo. 2003. Release of six sweetpotato cultivars ('Naspot 1' to 'Naspot 6') in Uganda. HortScience 38:475-476.

Parrella, G., A. Moretti, P. Gognalons, M.-L. Lesage, G. Marchoux, K. Gebre-Selassie, and C. Caranta. 2004. The Am gene controlling resistance to alfalfa mosaic virus in tomato is located in the cluster of dominant resistance genes on chromosome 6. Phytopathology 94:345-350.

Pio-Ribeiro, G., S. Winter, R.L. Jarret, J.W. Demski, and R.I. Hamilton. 1996. Detection of sweet potato virus disease-associated closterovirus in a sweet potato accession in the United States. Plant Dis. 80:551-554.

Pruss, G., X. Ge, X.M. Shi, J.C. Carrington, and V.B. Vance. 1997. Plant viral synergism: The potyviral genome encodes a broad-range pathogenicity enhancer that transactivates replication of heterologous viruses. Plant Cell 9:859-868.

Rosa, G.J.M., J.P. Steibel, and R.J. Tempelman. 2005. Reassessing design and analysis of two-colour microarray experiments using mixed effects models. Comp. Funct. Genomics 6:123-131.

Salazar, L.E. and S. Fuentes. 2000. Current knowledge on major virus diseases of sweetpotatoes. Proc. Intl. Wkshp. Sweet potato Cultivar Decline Study, Miyakonojo, Japan. p. 14-19.

Saldanha, A.J. 2004. Java Treeview: Extensible visualization of microarray data. Bioinformatics 20:3246-3248.
Senthil, G., H. Liu, V.G. Puram, A. Clark, A. Stromberg, and M.M. Goodin. 2005. Specific and common changes in Nicotiana benthamiana gene expression in response to infection by enveloped viruses. J. Gen. Virol. 86:2615-2625.

Shimizu, T., K. Satoh, S. Kikuchi, and T. Omura. 2007. The repression of cell wall- and plastid-related genes and the induction of defenserelated genes in rice plants infected with rice dwarf virus. Mol. Plant Microbe Interact. 20:247-254.

Storey, J.D. 2002. A direct approach to false discovery rates. J. R. Stat. Soc. B 64:479-498.

Van Damme, E.J.M. 2008. Plant lectins as part of the plant defense system against insects, p. 285-307. In: A. Schaller (ed.). Induced plant resistance to herbivory. Springer, Frankfurt, Germany.

Vance, V.B. 1991. Replication of potato virus X RNA is altered in coinfections with potato virus Y. Virology 182:486-494.

Vance, V.B., P.H. Berger, J.C. Carrington, A.G. Hunt, and X.M. Shi. 1995. 5' proximal potyviral sequences mediate potato virus X/ potyviral synergistic disease in transgenic tobacco. Virology 206: 583-590.

Van Damme, E.J.M., A. Barre, P. Verhaert, P. Rougé, and W.J. Peumans. 1996. Molecular cloning of the mitogenic mannose/ maltose-specific rhizome lectin from Calystegia sepium. FEBS Lett. 397:352-356.

Whitham, S.A., C. Yang, and M.M. Goodin. 2006. Global impact: Elucidating plant responses to viral infection. Mol. Plant Microbe Interact. 19:1207-1215.

Wise, R.P., M.J. Moscou, A.J. Bogdanove, and S.A. Whitham. 2007. Transcript profiling in host-pathogen interactions. Annu. Rev. Phytopathol. 45:329-369.

Wolfinger, R.D., G. Gibson, E.D. Wolfinger, L. Bennett, H. Hamadeh, P. Bushel, C. Afshari, and R.S. Paules. 2001. Assessing gene significance from cDNA microarray expression data via mixed models. J. Comput. Biol. 8:625-637.

Yang, C., R. Guo, F. Jie, D. Nettleton, J. Peng, T. Carr, J.M. Yeakley, J.-B. Fan, and S.A. Whitham. 2007. Spatial analysis of Arabidopsis thaliana gene expression in response to turnip mosaic virus infection. Mol. Plant Microbe Interact. 20:358-370.

Yang, Y.H., S. Dudoit, P. Luu, D.M. Lin, V. Peng, J. Ngai, and T.P. Speed. 2002. Normalization for cDNA microarray data: A robust composite method addressing single and multiple slide systematic variation. Nucleic Acids Res. 30:e15. 